\title{
Livelihood Activities and the Role of Livestock in Smallholder Farming Communities of Southern Zambia
}

\author{
Gelson Tembo ${ }^{1 *}$, Alice Tembo², Fusya Goma ${ }^{3}$, Evans Kapekele ${ }^{4}$, Jairos Sambo' \\ ${ }^{1}$ Department of Agricultural Economics, University of Zambia, Lusaka, Zambia \\ ${ }^{2}$ Ministry of Mines, Energy and Water Development, Luanshya, Zambia \\ ${ }^{3}$ Veterinary Department, Ministry of Agriculture and Livestock, Lusaka, Zambia \\ ${ }^{4}$ Disaster Management and Mitigation Unit (DMMU), Lusaka, Zambia \\ Email: ${ }^{*}$ tembogel@gmail.com
}

Received 20 February 2014; revised 24 March 2014; accepted 31 March 2014

Copyright (C) 2014 by authors and Scientific Research Publishing Inc.

This work is licensed under the Creative Commons Attribution International License (CC BY).

http://creativecommons.org/licenses/by/4.0/

(c) (i) Open Access

\section{Abstract}

This study represents one of the first comprehensive mixed-methods studies on the livelihood activities and the position of livestock in the hierarchy of these activities among households in livestock-rearing communities of southern Zambia. The results identify livestock as the most important source of income and the second most important source of livelihood in general. Seasonality analysis also shows that livestock is very important in mitigating against hunger during lean periods between November and March. The study also identifies the richer households as the ones that benefit the most from livestock as a source of income. Policy and other interventions need to recognize not only the relative standing of livestock in these communities but also the fact that the livestock sub-sector is not the same to all rural households.

\section{Keywords}

Livestock; Livelihoods; Income; Shocks; Mixed-Methods; Zambia

\section{Introduction}

In many Southern African Development Community (SADC) countries, chronic vulnerability and poverty are entrenched and exacerbated by the ever-present risk of extreme climatic (drought and floods), economic and

${ }^{*}$ Corresponding author. 
policy shocks. For most of these shocks and risks, food insecurity has been perceived mainly in terms of food crop availability and accessibility. The role of livestock, which touches upon the livelihoods of approximately 60 percent of the people in Southern Africa, is not fully appreciated. This neglect of the role livestock plays is partly due to lack of solid empirical evidence on the actual contribution livestock make to livelihoods and the survival strategies that are employed during times of shocks. Understanding the role of livestock in more specific terms could facilitate development of informed policy and other intervention strategies aimed at further strengthening the livestock-based livelihood systems. In Zambia, this knowledge is especially critical in livestock-based livelihood systems of Southern Province, where droughts and seasonal hunger are frequent and, often, rural people have to turn to their livestock as a coping strategy. Of the country's 10 provinces, Southern Province also stands out as one with the largest and most diversified smallholder livestock sub-sector. Unfortunately, there is a glaring dearth of empirical evidence on the underlying livelihood systems and the position of livestock in the hierarchy of livelihood activities. Elsewhere, studies have shown that livestock could impact nutritional status [1] [2], income [1] [3]-[7]) and rural poverty [4] [8].

The study presented in this paper represents one of the first comprehensive mixed-methods treatments of the role of livestock as a source of livelihood and income, and in risk management against shocks. This study will assist policy makers and stakeholders in mainstreaming livestock intervention strategies in Zambia by understanding the livelihood systems and defining the role that livestock plays among livestock-owning smallholder households. In the remainder of the paper, we first present the methods and procedures used in Section two, followed by results and discussions in Section three. Summary and conclusion are presented in Section four.

\section{Methods and Procedures}

\subsection{Sample Design and Sampling}

This study uses data from a mixed-methods survey of livestock-rearing communities in three districts of the Southern Province of Zambia, conducted during the 2006/2007 agricultural season. Southern Province is comprised of 11 districts, half of which are located in the low-rainfall (less than $800 \mathrm{~mm}$ annual rainfall) region, agro-ecological region (AER) I. This group of districts can be further sub-divided into valley districts and those that are located in the sandy plateau in the south-western part of the province. We call both these sub-categories of districts "hot-spot" districts, owing to their high poverty and vulnerability levels. The other six districts belong to medium-rainfall ( 800 - $1200 \mathrm{~mm}$ ) region, AER II, here referred to as non-hotspot districts.

One district was randomly selected from each of these strata-one from each of the hot-spot sub-categories (Sinazongwe from the valley stratum; and Kazungula from the sandy plateau stratum), and one from the non-hotspot stratum (Namwala). Within each selected district and prior to primary data collection, all the veterinary camps or communities were stratified into four distinct groups based on relative productive potential (high or low) and market access (high or low). This was accomplished in close consultation with knowledgeable key informants such as the District Veterinary Officer (DVO) and his/her staff. One community was then randomly selected from each of the four camp/community strata.

\subsection{Community Mapping and Wealth Ranking}

In each selected community, a number of complementary quantitative and qualitative research techniques were used to collect the required data and information. Participants were drawn from within the livestock-rearing communities. The community participatory assessment process begun with a social mapping exercise to characterize the community's institutional, resource and asset context as well as to categorize the individual households based on their degree of vulnerability to food insecurity. This was done using participatory wealth ranking techniques, in which the community assigned the wealth status on each and every member of the community through a participatory process. Through this process, households were grouped into three strata-1) food secure (FS) or non-poor (NP), 2) food insecure (FI) or poor (P), and 3) extremely food insecure (EFI) or extremely poor (EP). For operational purposes, a household was categorized as non-poor if it had enough to eat throughout the year, i.e. from harvest to harvest; as poor if it normally had enough food to last from harvest up to Christmas but not between Christmas and the next harvest; and as extremely poor if it had a longer period of food shortages, often experiencing severe food shortages even before Christmas. 


\subsection{Focus Group Discussions and Activity Rankings}

Within each wealth stratum, focus groups were convened, each comprising a random sample of 8 - 10 individuals. In addition to being a powerful tool for collecting data that is enriched by purposeful use of interaction [9]-[12], Focus Group Discussions (FGDs) also offer considerable advantages in terms of cost per informant. The number of participants per FGD was determined in conformity with recommendations of some sections of the literature. Similarly, the number of FGDs per district was arrived at taking recommendations in the literature into account. Reference [13], for example, suggests an optimal number of FGDs of 4 - 12 while [14] contends that data generated after about 10 FGDs are likely to be largely redundant.

During the focus group discussions a number of standard participatory tools were used to identify the issues and livelihood activities, and to determine the relative importance of the identified alternatives. These included tools such as participatory scoring and pair-wise ranking. Relative importance and seasonality of livelihood and income-generating activities were derived by using analytical calendars with scoring. Analytical calendars are matrices with each row representing a competing activity and each column representing the month. The activities in the analytical calendar are arrived at by the communities through a participatory process. Once this is done, two types of scoring are then undertaken. Vertical scoring, usually by distributing a fixed number of grains (say, 100), is done to determine the relative importance of each competing activity, overall and without taking seasonality into account. The more the grains assigned to the activity the more important the community considers the activity to be. The second type of scoring involves, for each activity, distributing the grains across the 12 months of the year. The months in which the activity is regarded to be important are assigned more grain. During seasonality analysis, the horizontal (monthly) scores are weighted by the relative importance of the activity/row as determined by the vertical scores. That is, the weight for each row entry is equal to the vertical score presented as a percentage of the total number of grains (e.g. 100). Unlike the unweighted seasonality (or row) scores, the weighted seasonality scores can be compared not only within activity but also across the activities.

\subsection{In-Depth Interviews}

During the community mapping and after all the households in the community had been identified, a very short questionnaire or listing form was administered to each of the identified households. A total of 309 households were listed and interviewed across all the communities in the three districts. While this information was important in its own right, the resultant list with wealth strata was also used as a sampling frame from which households were randomly selected for in-depth interviews. Using a semi-structured questionnaire, each in-depth household interview deciphered basic socio-economic characteristics and livelihood activities of each household. Care was taken to ensure representation of each of the wealth strata in these household case studies. A total of 56 household interviews were completed using a semi-structured questionnaire.

\subsection{Analysis}

Data collected through the wide spectrum of methods and instruments discussed above were analyzed using a wide range of techniques. These included post-interview brainstorming and collation of notes (for qualitative information), and quantitative analysis of rank/score data and scale data collected using pre-designed tables and semi-structured questionnaires. The quantitative analyses were accomplished using Microsoft Excel and the Statistical Package for Social Sciences (SPSS).

\section{Results and Discussion}

The study area represents diverse livelihood systems comprising varying combinations of agricultural and non-agricultural activities. To help understand the intra- and inter-community variations in livelihood activities, the study used focus group discussions consisting of fairly homogeneous groups of community members. Four focus group discussions were carried out in each district for each food security stratum, one in each of the four sample communities. Each of these focus groups was asked to list the activities that constitute their livelihood system. Commonly listed activities included field crop production, livestock sales, gardening, fishing, wage and/or salaried employment (piece work), gathering and sale of forest products (grass, charcoal, honey, wild fruits, wood, etc.), crafts (carpentry, mat weaving, black-smith, knitting, etc.), beer brewing, hiring out animal draught power (ADP) for ploughing and transportation, selling animal products (milk, meat, eggs, etc.), and 
trading (sell of groceries and other necessities, commonly referred to as tu nthemba). The fact that smallholder livelihood systems are highly diversified is well documented in the literature [5]. Small-scale farmers have these diversified livelihood systems to help them cope during times of uncertainties which may include crop and market failures.

\subsection{Livelihood Activities}

Table 1 shows the numbers in each district of focus groups that indicated performing each livelihood activity, disaggregated by food security status. In columns (1) through (9), the entries range from zero (0), if none of the focus groups (per district) identified the livelihood activity in question as one of their means of survival, to four, if all the four focus groups mentioned the activity. Column (10) presents the total number of focus groups interviewed that identified the activity as an important source of livelihood, out of the 36 focus groups that were interviewed during the course of the study.

Field crop production is the most prevalent source of livelihood in the study area, indicated by 35 (or 97 percent) of the 36 focus groups (Column 10), followed by livestock (78 percent), gardening (72 percent), piece work (53 percent), and fishing (42 percent). The importance of field crop production and livestock in smallholder farming communities has been echoed throughout much of Africa (see, for example, [5] on Tanzania). Geographical and inter-strata variations in the composition of livelihood activities were also quite apparent. Field crops and livestock were mentioned by all the food security groups in the non-hotspot district (Namwala). Among the hotspot districts (Kazungula and Sinazongwe), only the extremely food insecure in one of the four Kazungula communities did not identify field crop production as their source of livelihood. The relative prevalence of livestock as a means of survival in the hotspot districts varies across food security categories, mentioned the least among extremely food insecure groups. Gardening, while being quite important in the hotspot districts, is not so important in Namwala, where only food insecure and extremely food insecure households use it as a source of livelihood.

Fishing and piece work are most prevalent in Sinazongwe District, where at least three-quarters of the interviewed focus groups mentioned them, and virtually non-existent among food secure households in the nonhotspot district, Namwala. Half of the food insecure and extremely food insecure focus groups in Namwala identified fishing as important. However, the importance of fishing has been put in check by the fact that the activity is rather specialized and the fact that fish have become progressively rarer. In all three districts, piece work is most common among the extremely food insecure.

Table 1. Diversity of livelihood activities across districts and food security status.

\begin{tabular}{|c|c|c|c|c|c|c|c|c|c|c|}
\hline \multirow{5}{*}{$\begin{array}{l}\text { Activity actually } \\
\text { mentioned by the } \\
\text { focus group }\end{array}$} & \multicolumn{6}{|c|}{ Hotspot districts } & \multirow{2}{*}{\multicolumn{3}{|c|}{ Namwala (Non-hotspot district) }} & \multirow{3}{*}{ Total } \\
\hline & \multicolumn{3}{|c|}{ Kazungula } & \multicolumn{3}{|c|}{ Sinazongwe } & & & & \\
\hline & $\begin{array}{l}\text { Food } \\
\text { secure }\end{array}$ & $\begin{array}{c}\text { Food } \\
\text { insecure }\end{array}$ & $\begin{array}{l}\text { Extremely } \\
\text { food insecure }\end{array}$ & $\begin{array}{l}\text { Food } \\
\text { secure }\end{array}$ & $\begin{array}{c}\text { Food } \\
\text { insecure }\end{array}$ & $\begin{array}{l}\text { Extremely } \\
\text { food insecure }\end{array}$ & $\begin{array}{l}\text { Food } \\
\text { secure }\end{array}$ & $\begin{array}{c}\text { Food } \\
\text { insecure }\end{array}$ & $\begin{array}{l}\text { Extremely } \\
\text { food insecure }\end{array}$ & \\
\hline & (1) & (2) & (3) & (4) & (5) & (6) & (7) & (8) & (9) & (10) \\
\hline & --- & ----------- & ----------------Nu & ber of fo & as groups & ndertaking the & lihood a & tivity $^{a}--$ & --------------------. & --- \\
\hline Field crops & 4 & 4 & 3 & 4 & 4 & 4 & 4 & 4 & 4 & 35 \\
\hline Livestock sales & 4 & 3 & 0 & 3 & 4 & 2 & 4 & 4 & 4 & 28 \\
\hline Gardening & 3 & 4 & 2 & 4 & 3 & 4 & 0 & 2 & 4 & 26 \\
\hline Fishing & 1 & 1 & 0 & 3 & 3 & 3 & 0 & 2 & 2 & 15 \\
\hline Piece work & 0 & 2 & 3 & 3 & 3 & 4 & 0 & 1 & 3 & 19 \\
\hline Forest products & 0 & 2 & 0 & 3 & 1 & 2 & 1 & 1 & 2 & 12 \\
\hline Crafts & 1 & 2 & 0 & 1 & 1 & 2 & 0 & 1 & 2 & 10 \\
\hline Beer brewing & 1 & 2 & 1 & 0 & 0 & 0 & 1 & 0 & 0 & 5 \\
\hline Hiring out ADP & 1 & 0 & 0 & 0 & 1 & 0 & 0 & 2 & 0 & 4 \\
\hline Selling milk & 1 & 1 & 0 & 0 & 0 & 0 & 1 & 1 & 0 & 4 \\
\hline Trading & 2 & 2 & 4 & 1 & 2 & 1 & 0 & 0 & 1 & 13 \\
\hline
\end{tabular}

${ }^{a}$ Out of four communities per district (Columns 1 - 9), or out of a total of 36 communities for the study (Column 10). 
Trading is most common in Kazungula District, which is not surprising being a border town next to the country's tourist capital, Livingstone. Because of the nature of the terrain and inadequate land in Sinazongwe, many communities have resorted to fishing considering the fact that there are no restrictions involved as to what time of the year fishing is allowed or who should/shouldn't fish. This is unlike in Namwala, where the main rivers such as Namwala and Kafue are only open for fishing over the period March through to November.

Table 2 presents the proportions of the interviewed focus groups that ranked each activity among the top three most important activities at the time of the survey (2006) and 10 years before (1996), disaggregated by district and food security category. Table 2 also confirms the importance of crop agriculture and livestock in the study area with 81 percent and 53 percent of all the focus groups ranking them among the top three, respectively (Column 4).

As expected, the relative importance of these two activities is higher as we go higher on the food security scale- towards the food secure stratum. More than 90 percent of the food secure, for example, ranked field crop production among the top three most important livelihood activities. The relatively lower weight placed on agriculture and livestock by the food insecure and extremely food insecure groups means that these groups place relatively higher weight on other activities. Gardening, for example, seems to be a significant preoccupation of the food insecure segments of the society, ranked highly by at least 58 percent of the groups. Piece work and trading are also quite important among these groups with about half the interviewed FI and EFI focus groups ranking them in the top three.

Compared to agriculture-based activities, piece work and trading are often regarded inferior and adopted as means for coping with harsh realities of food insecurity. Thus, the waning importance of field crops and livestock and growing importance of piece work over the 10 years prior to the survey (compare Column 4 with Column 8) suggest an increase in levels of vulnerability. The importance of livestock as a source of livelihood went down by 21 percent (from 66.7 percent to 52.8 percent) while gardening increased by as much as 29 percent (from 38.9 percent to 50.0 percent) between 1996 and 2006. However, the fact that crops and livestock are important sources of livelihood shows that agriculture is key in these communities. While crops of various types are very important in day to day life during normal years, livestock have from time to time played the role of a life saver during bad seasons.

Cattle were the most prevalent animals, especially in the non-hotspot district, Namwala (Figure 1(a)). Namwala had about 100,000 cattle, which is almost twice as much as in the other two districts (Kazungula and Sinazongwe). Sinazongwe had the lowest cattle population, of about 52,000, while Kazungula had about 60,000.

Table 2. Relative importance and trends in livelihood activities in Kazungula, Namwala and Sinazongwe Districts of Zambia, 2006 and 1996.

\begin{tabular}{|c|c|c|c|c|c|c|c|c|}
\hline \multirow{4}{*}{ Livelihood activity } & \multicolumn{4}{|c|}{ At time of survey (2006) } & \multicolumn{4}{|c|}{10 years before $(1996)$} \\
\hline & $\begin{array}{l}\text { Food } \\
\text { secure }\end{array}$ & $\begin{array}{c}\text { Food } \\
\text { insecure }\end{array}$ & $\begin{array}{l}\text { Extremely food } \\
\text { insecure }\end{array}$ & Total & $\begin{array}{l}\text { Food } \\
\text { secure }\end{array}$ & $\begin{array}{c}\text { Food } \\
\text { insecure }\end{array}$ & $\begin{array}{l}\text { Extremely food } \\
\text { insecure }\end{array}$ & Total \\
\hline & (1) & (2) & (3) & (4) & (5) & (6) & (7) & (8) \\
\hline & \multicolumn{8}{|c|}{ 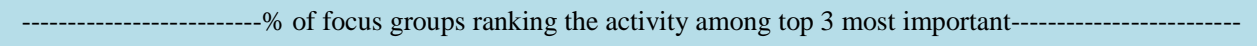 } \\
\hline Field crops & 91.7 & 75.0 & 75.0 & 80.6 & 91.7 & 91.7 & 83.3 & 88.9 \\
\hline Livestock & 75.0 & 50.0 & 33.3 & 52.8 & 91.7 & 75.0 & 33.3 & 66.7 \\
\hline Gardening & 25.0 & 66.7 & 58.3 & 50.0 & 16.7 & 50.0 & 50.0 & 38.9 \\
\hline Fishing & 25.0 & 8.3 & 8.3 & 13.9 & 33.3 & 0.0 & 8.3 & 13.9 \\
\hline Piece work & 8.3 & 16.7 & 50.0 & 25.0 & 8.3 & 25.0 & 33.3 & 22.2 \\
\hline Forest products & 0.0 & 8.3 & 8.3 & 5.6 & 0.0 & 8.3 & 8.3 & 5.6 \\
\hline Beer brewing & 8.3 & 8.3 & 0.0 & 5.6 & 16.7 & 16.7 & 8.3 & 13.9 \\
\hline Crafts & 8.3 & 16.7 & 16.7 & 13.9 & 8.3 & 16.7 & 16.7 & 13.9 \\
\hline Hiring out oxen & 0.0 & 8.3 & 0.0 & 2.8 & 0.0 & 8.3 & 0.0 & 2.8 \\
\hline Selling milk & 8.3 & 0.0 & 0.0 & 2.8 & 8.3 & 0.0 & 0.0 & 2.8 \\
\hline Trading & 16.7 & 8.3 & 50.0 & 25.0 & 0.0 & 0.0 & 50.0 & 16.7 \\
\hline
\end{tabular}


Goats and poultry (small livestock) were most important in Sinazongwe with a goat population of more than 50,000 and that of poultry about 32,000. Sinazongwe had 7 times the goat population as did the closest district, Namwala. Sheep and pigs were considered important in Sinazongwe with the population higher than that of the other districts. Of all the three districts, Kazungula had the least populations of goats, poultry, and other relatively minor livestock.

The relative importance of cattle is also evident in the qualitative assessment, with most of the communities assigning a rank of 1 (Figure 1(b)). Goats are the second most important livestock species reared, followed by poultry (Figure 1(b)). The importance of cattle and goats among the food security groups is also evidenced in a study by [3] in the rural areas of South Africa. Sheep, donkeys, and pigs are the least important species carrying a mean rank of more than three (3) among all the food security groups.

\subsection{Income Generation}

Field crops and livestock are the two most important sources of income, together representing almost half of the income earned by rural households. These results are consistent with [4], who found that field crops generated most of the livelihood incomes across social groups in West Africa (i.e. very poor, poor, relatively rich). When animal products and services (e.g. hiring out animal draught power) are considered, the contribution of the two sources to income extends to about 60 percent. While field crop production received a higher score as a livelihood activity in a more general sense than did livestock rearing, livestock and their products represent a much more important source of income. When only live animals and meat sales are considered, livestock generate 26 percent of all income earned by the households, compared to field crops' 21 percent. When animal products (eggs, milk, skins, manure, etc) are taken into account, the contribution of livestock swells to 39 percent, which is almost double the contribution of field crops. The dominance of livestock as an income earner holds both in the total sample (Column 7 in Table 3) as well as among most individual food security sub-samples. This is consistent with the national picture in which livestock is argued to contribute at least 50 percent of agricultural gross domestic product (GDP) [15].

Generally, small scale farmers grow most of their field crops for consumption and only sell a few when need arises. On the contrary, livestock is rarely eaten but rather sold to solve household problems (school fees, clothes, hummer mill services, health expenses, etc.). In a non-hotspot district, one was considered wealthy depending on the number of cattle one owned. Cattle are sold for other various purposes such as building a house, dowry payments, and settling conflicts (e.g. murder, adultery, pregnancy, theft) and exchanged for other

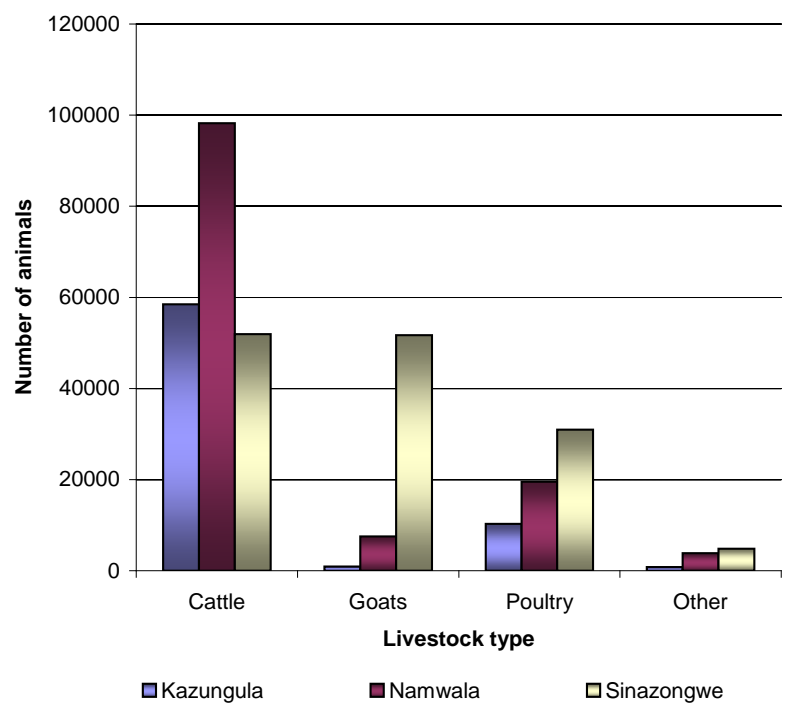

(a)

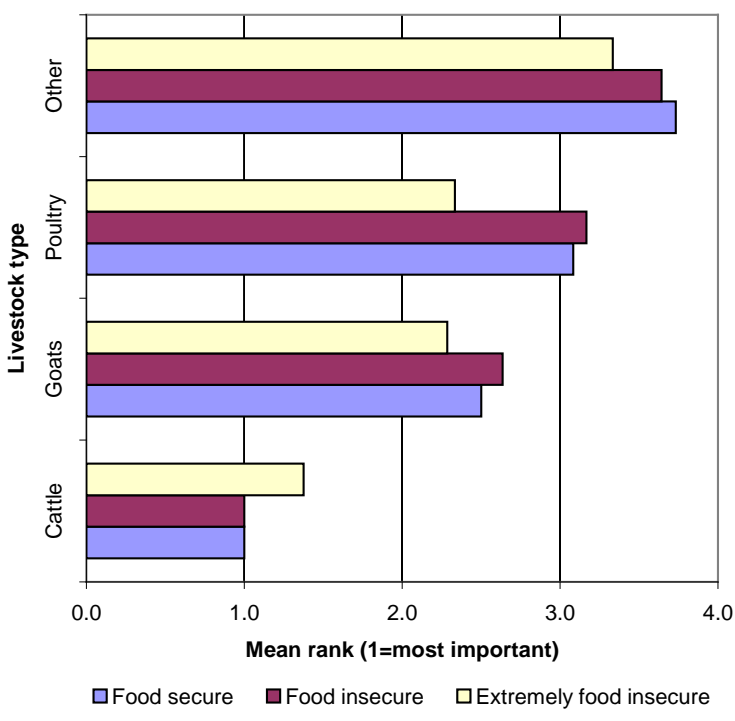

(b)

Figure 1. Numbers of livestock species and their relative importance to livelihoods, September 2006. Sources: Livestock numbers from Department of Veterinary and Livestock Development (DVLD). (a) Livestock population; (b) Rank of the livestock species $(1$ = most important). 
Table 3. Sources of income and their relative importance across food security status and district types, September 2006.

\begin{tabular}{|c|c|c|c|c|c|c|c|}
\hline \multirow{4}{*}{ Source of income } & \multicolumn{3}{|c|}{ Hotspot districts } & \multicolumn{3}{|c|}{ Non-hotspot district } & \multirow{2}{*}{ Total } \\
\hline & $\begin{array}{l}\text { Food } \\
\text { secure }\end{array}$ & $\begin{array}{l}\text { Food } \\
\text { insecure }\end{array}$ & $\begin{array}{c}\text { Extremely } \\
\text { food insecure }\end{array}$ & $\begin{array}{l}\text { Food } \\
\text { secure }\end{array}$ & $\begin{array}{c}\text { Food } \\
\text { insecure }\end{array}$ & $\begin{array}{c}\text { Extremely } \\
\text { food insecure }\end{array}$ & \\
\hline & (1) & (2) & (3) & (4) & (5) & (6) & (7) \\
\hline & \multicolumn{7}{|c|}{ 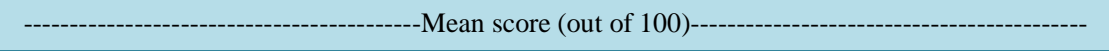 } \\
\hline Field crops sales & 20.4 & 13.9 & 25.4 & 25.3 & 27.0 & 17.5 & 20.9 \\
\hline Livestock sales $^{a}$ & 27.4 & 24.9 & 20.1 & 43.3 & 26.8 & 25.0 & 26.2 \\
\hline Other animal products ${ }^{b}$ & 12.5 & 3.1 & 3.0 & 10.3 & 5.3 & 12.0 & 7.1 \\
\hline Hiring out ADP & 11.3 & 7.1 & 2.3 & 3.4 & 4.8 & 3.0 & 5.9 \\
\hline Piece work & 10.9 & 14.3 & 26.8 & 0.0 & 5.3 & 19.3 & 14.6 \\
\hline Gardening & 6.3 & 13.6 & 9.8 & 0.0 & 6.5 & 7.3 & 8.3 \\
\hline Fishing & 3.5 & 6.9 & 1.5 & 0.0 & 3.5 & 5.0 & 3.7 \\
\hline Other $^{c}$ & 7.9 & 16.3 & 11.3 & 17.7 & 21.0 & 11.5 & 13.3 \\
\hline
\end{tabular}

${ }^{a}$ Livestock are sold both whole and as meat; ${ }^{b}$ Other animal products mentioned by the communities included milk, eggs, skins, and manure; ${ }^{c}$ Other income sources include hammer mill revenue (service and crop byproducts), remittances, selling of forest products, crafts, beer brewing, trading, traditional healing, guest house services, and cash transfers from NGOs.

assets including vehicles. After livestock and field crops, piece work is the next most important income source (15 percent), followed by a group of activities that we have grouped into the category "other" (13 percent). It is important to note that the contribution of livestock to income is largest among food secure households with an even larger prominence in the non-hotspot district. Piece work, on the other hand, is clearly most prominent among the extremely food insecure and most visible in the hotspot districts. Compared to all other food security groups, food insecure households appeared to have the most diversified set of income sources, with a significantly larger weight on numerous other minor sources collectively referred to as 'other' than any other group of households.

Table 3 presents a total annual picture, which greatly masks the dips and peaks along the year and the households' abilities to mitigate the harder periods. Figure 2 shows the seasonality of the four most important income sources as depicted by weighted monthly scores-field crops (Figure 2(a)), livestock sales (Figure 2(b)), piece work (Figure 2(c)), and other sources (Figure 2(d)) —and how the seasonal patterns differ by the household's food security status. Field crops are most important during and just after harvest, in the months of April through September. But the exact length of this crop income boom period differs markedly by food security status. While the extremely food insecure sell their crops almost immediately after harvest, the relatively more food secure households (FI and FS) are able to delay their sales and hence stretch the period further.

One could speculate that this is because the more food secure households: 1) are less desperate to sell their crop at harvest as they have other means of survival, 2) have relatively larger harvests that need to be sold over an extended period of time, and/or 3) have better technical know-how for storing crops. Whatever the reason, the fact that the poorer households sell their produce at and/or immediately after harvest implies that they receive the lowest prices for them, a fact that could further strengthen the poverty vicious cycle, continually widening the gap between the poor and the richer segments of the society.

Figure 2(b) and Figure 2(c) seem to present a picture opposite to that presented in Figure 2(a). Livestock sales and piece work both are most prominent the further we are from the harvest period-October through February. While the general pattern of the two figures is the same across wealth strata, it appears the more food secure the household is the larger the weight on livestock sales. This pattern is more clearly defined during the first quarter of the calendar year. Also, as expected, piece work was much more heavily weighted by extremely food insecure focus groups.

Figure 2(d) further reinforces the argument that the food insecure households have a much more diverse set of income sources, placing significantly higher weights on the category "other" throughout the year. Compared to the other three income sources in Figure 2, this latter category does not have any special seasonal pattern. Livestock sales and piece work are high at the beginning and end of the year partly because this period coincides 


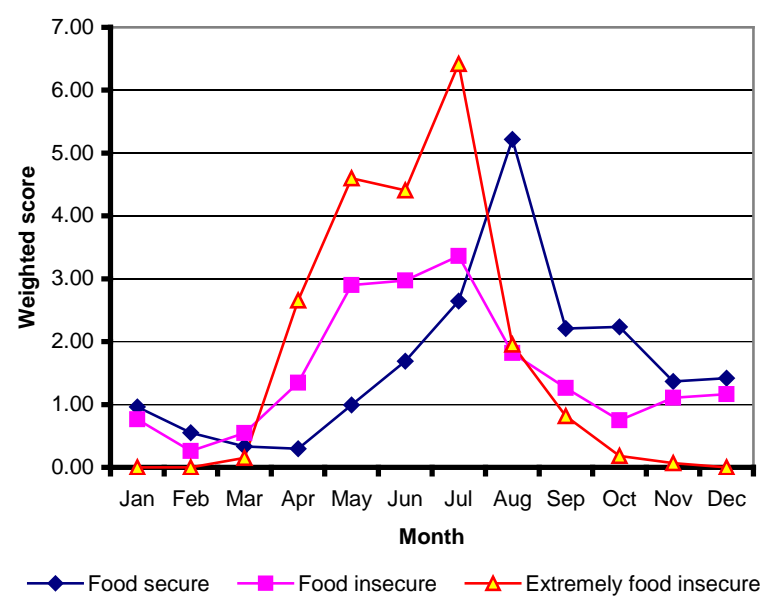

(a)

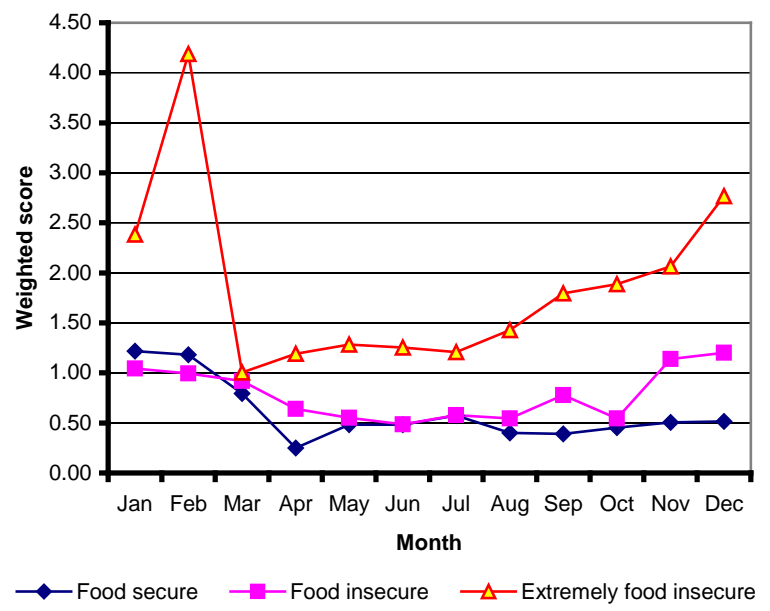

(c)

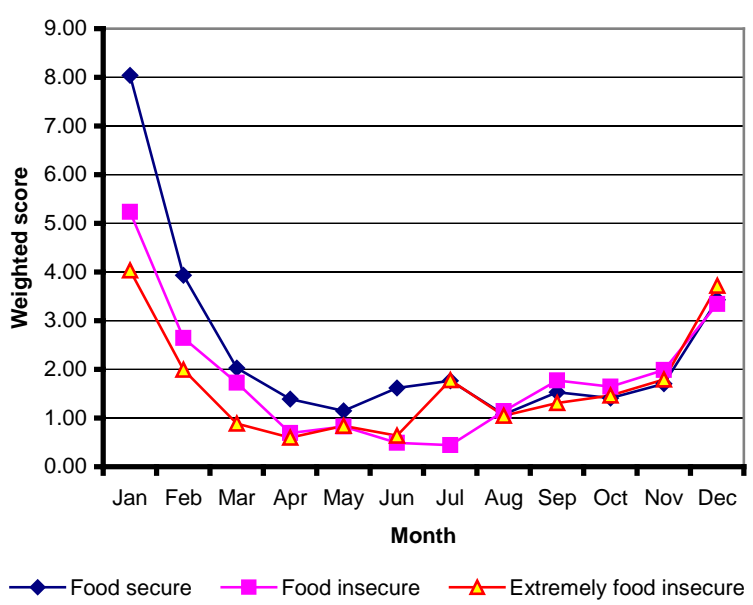

(b)

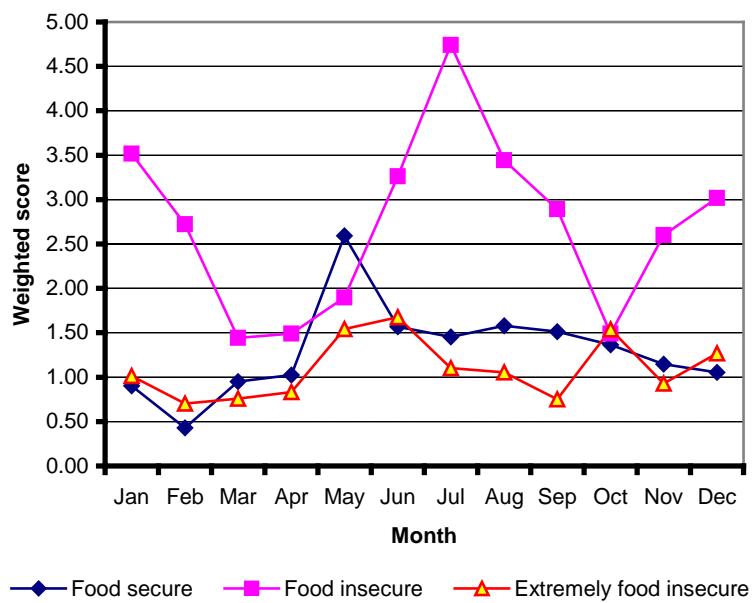

(d)

Figure 2. Seasonality of the four most important income sources, differentiated by food security status, 2006. (a) Field crops; (b) Livestock sales; (c) Piece work; (d) Other.

with the festive season in addition to being the time that parents prepare school fees as their children move into higher levels of education. Moreover, this is also the lean period of the year during which food stocks will have run out in most households.

\section{Summary and Conclusion}

This study uses qualitative research techniques to identify the livelihood activities and to determine the position of livestock in the hierarchy of those activities among households in livestock-rearing communities of Southern Zambia. Seasonality analysis was also done to identify the shifts in relative importance of the activities across the different times of the year. The results indicate that, when livelihood is broadly defined, livestock rearing is second only to field crop production both in terms of prevalence (number of communities citing it) and relative importance (as indicated by weighting exercises). However, livestock and livestock-related products and services are by far the most important source of income. Livestock as a source of income is especially important among the food secure households, who earn more than half of their income through sales of livestock, livestock products (milk, eggs, meat, manure) and livestock-related services (hiring out of animal drought power), compared to less than 40 percent among other food security groups. That livestock is important as sources of livelihoods and, especially, income identifies the need to identify and implement interventions that could enhance livestock ownership and productivity. While food secure households are more commercial in approach, less food secure households have their sustenance and subsistence in mind. This inherent dichotomy in approach to livelihood 
needs to be reflected in intervention design and implementation.

\section{Acknowledgements}

This study is in part based on work done by the authors for the International Livestock Research Institute (ILRI) and the Food and Agriculture Organization of the United Nations (FAO). However, the views expressed in this paper do not necessarily represent the official positions of ILRI and/or FAO. All errors in interpretation are the authors' own.

\section{References}

[1] Biradar, N., Desai, M., Manjunath, L. and Doddamani, M.T. (2013) Assessing Contribution of Livestock to the Livelihood of Farmers of Western Maharashtra. Journal of Human Ecology, 41, 107-112.

[2] Kassa, H., Ayalew, W., Habte, G.Z. and Gebre, M.T. (2003) Enhancing the Role of Livestock Production in Improving Nutritional Status of Farming Families: Lessons from a Dairy Goat Development Project in Eastern Ethiopia. Livestock Research for Rural Development, 15. http://www.lrrd.org/lrrd15/6/kass156.htm

[3] Chaminuka, P., Udo, H.M.J., Eilers, K.C.H.A.M. and Zijpp, A.V.D. (2014) Livelihood Roles of Cattle and Prospects for Alternative Land Uses of Wildlife/Livestock Interface in South Africa. Land Use Policy, 38, 80-90. http://dx.doi.org/10.1016/j.landusepol.2013.10.007

[4] Mburu, S., Zaibet, L., Fall, A. and Ndiwa, N. (2012) The Role of Working Animals in the Livelihoods of Rural Communities in West Africa. Livestock Research for Rural Development, 24. http://www.lrrd.org/lrrd24/9/mbur24156.htm

[5] Lwelamira, J., Binamungu, H.K. and Njau, F.B. (2010) Contribution of Small Scale Dairy Farming under Zero-Grazing in Improving Household Welfare in Kayanga Ward, Karagwe District, Tanzania. Livestock Research for Rural Development, 22. http://www.lrrd.org/lrrd22/2/lwel22031.htm

[6] Mabe, L.K., Antwi, M.A. and Oladele, O.I. (2010) Factors Influencing Farm Income in Livestock Producing Communities of North-West Province, South Africa. Livestock Research for Rural Development, 22. http://www.lrrd.org/lrrd22/8/mabe22142.htm

[7] Dovie, D.B.K., Shackleton, C.M. and Witkowski, E.T.F. (2006) Valuation of Communal Areas Livestock Benefits, Rural Livelihoods and Related Policy Issues. Land Use Policy, 23, 260-271. http://dx.doi.org/10.1016/j.landusepol.2004.08.004

[8] Holmann, F., Rivas, L., Urbina, N., Rivera, B., Giraldo, L.A., Guzman, S., Martinez, M., Medina, A. and Ramirez, G. (2005) The Role of Livestock in Poverty Alleviation: An Analysis of Colombia. Livestock Research for Rural Development, 17. http://www.lrrd.org/lrrd17/1/holm17011.htm

[9] Kitzinger, J. (1994) The Methodology of Focus Groups: The Importance of Interaction between Research Participants. Sociology of Health and Illness, 16, 103-121. http://dx.doi.org/10.1111/1467-9566.ep11347023

[10] McLafferty, I. (2004) Focus Group Interviews as a Data Collecting Strategy. Journal of Advanced Nursing, 48, 187194. http://dx.doi.org/10.1111/j.1365-2648.2004.03186.x

[11] Merton, R.K., Fiske, M. and Kendall, P.L. (1990) The Focused Interview: A Manual of Problems and Procedures. 2nd Edition, Free Press, New York.

[12] Morgan, D. (1996) Focus Groups. Annual Reviews of Sociology, 22, 129-152. http://psycho.univ-lyon2.fr/sites/psycho/IMG/pdf/Morgan fc v2.pdf http://dx.doi.org/10.1146/annurev.soc.22.1.129

[13] Krueger, R. and Casey, M.A. (2009) Focus Groups: A Practical Guide for Applied Research. 4th Edition, Sage Publications Limited, London.

[14] Millward, L. (1995) Focus Groups. In: Breakwell, G., Hammond, S. and Fife-Schaw, C., Eds., Research Methods in Psychology, 4th Edition, Sage Publications Limited, London.

[15] Daka, D. E. (2002) Livestock Sector in Zambia: Opportunities and Limitations. In: IAEA (International Atomic Energy Agency), Eds., Development and Field Evaluation of Animal Feed Supplementation Packages, Proceedings of the Final Review Meeting, Cairo, 25-29 November 2000. http://www-naweb.iaea.org/nafa/aph/public/reports-12.pdf 